\title{
Entrepreneurship Courses on Gamification Strategies
}

\author{
Nisaul Barokati Seliro Wangi ${ }^{1}$, M. Hafidh Nashrullah ${ }^{2}$ \\ 12 Universitas Islam Darul Ulum Lamongan \\ nisa@unisda.ac.id, hafidh@unisda.ac.id
}

\begin{abstract}
In the learning process, the gamification strategy plays an important role in determining the achievement of learning objectives. Learning objectives will be achieved if students are able to engage in active communication both with their peers, facilitators, and with other learning resources. Characteristics of entrepreneurship courses include understanding and appreciation of entrepreneurship, the role of entrepreneurial mental attitude for self-improvement and institutions with core entrepreneurial spirit and entrepreneurial mental attitude through the introduction of entrepreneurial characteristics, growing business interest and tips on successful entrepreneurs, making business plans and making business plans. The aim of entrepreneurship courses is to provide students with an understanding and appreciation of entrepreneurship that is increasingly felt important in the face of globalization. Gamification and entrepreneurship Having several links (1) gamification strategies can provide choices and control to students when making a plant business project, (2) gamification strategies can foster confidence in their ability to face and solve challenges, (3) gamification strategies provide material and key answers to entrepreneurship courses, (4) give appreciation for the additional learning taken, and (5) help students establish social interaction through leadership activities or other social interactions. This development research seeks to design a gamification strategy in entrepreneurship courses in the Indonesian Language and Literature Study Program, FKIP UNISDA Lamongan. The Gamification Strategy developed has four basic game components, namely the rules of gamification, feedback (leaderboards, prizes, and medals), goals, and challenges. This research includes the type of development research that uses the Lee and Owl model with the following stages, (1) analyzing needs, (2) pre-test and posttest analysis, (3) design, (4) development, (5) implementation, (6) evaluation. Results of developing a gamification strategy package (1) gamification strategy (2) Lecturer guidance (3) student guide (4) Entrepreneurship book.
\end{abstract}

Keyword: Strategy, Gamification, Entrepreneurship Course

\section{INTRODUCTION}

The emergence of the phenomenon of dependence of productive age communities (between 17-40 years) on games and the fact that the growth of game users in Indonesia reaches $30 \%$ per year makes practitioners and developers of the world try to learn the elements of the game. In the scientific field, the application of game elements in non-game applications is known as gamification. In learning, gamification can be applied as a strategy and / or media to improve the quality of learning and provide 
achievement motivation. Achievement motivation that follows the learning process will have an impact on student learning outcomes (Li et al, 2012).

According to the lecturer who is in charge of Entrepreneurship courses, there are only a few active students, which is around 7.4\% of the total students. As for the rest, $92.59 \%$ of all students, only silent or passive without any desire to interact with lecturers.

The low student learning outcomes can be caused by the ability to think and understanding concepts that are weak. In the future, this will affect the students' skills in solving life problems. If you already have the ability to solve problems, in addition to being able to solve similar problems, one can also solve different problems in everyday life (Bransford, Sherwood, Vye, \& Rieser, 1986; Gagne, 1985; Gagné, Briggs, \& Wager, 1992).

As an educational institution, Darul Ulum Lamongan University (Unisda) has sought to provide facilities and make it easy for students to take part in learning activities. One form of fulfillment of these facilities is the procurement of e-lerning for a number of courses, including the Entrepreneurship course. With e-learning, students can learn flexibly, without being bound by time and space. As a result, Unisda students from outside the Lamongan area can still take part in learning well, without worrying about being left behind.

The selection of the web as a medium for gamification is appropriate. Besides being in line with the concept of e-learning utilizing the internet network with the web as the main portal of information delivery the web has unlimited space to support the purpose of applying gamification. In Entrepreneurship courses, gamification can be used to make students feel happier and challenged in following the learning process. When they feel challenged, the level of student achievement motivation will also increase and can be sure there are positive changes in student learning outcomes (grades).

\section{LITERATURE REVIEW}

\section{Gamification Strategy}

The term 'Gamification' was first used in 2008 from digital media (Deterding, Dixon, Khaled, \& Nacke, 2011). By Deterding, Dixon, Khaled, \& Nacke (2011) the term is defined as the application of mechanical games such as non-game situations or contexts. Meanwhile, Kapp (2014) defines Gameplay as a strategy that uses mechanisms, aesthetics, and game thinking to engage people, motivate achievement, embody learning, and solve problems (Kapp, 2014).

Based on these two opinions, it can be concluded that the game is a learning strategy that implements game elements in non-game applications with the aim of binding and motivating users to solve a problem. In this strategy, existing material or technology is presented in a more attractive format. The attractiveness of the dish will encourage its users, for example students to get involved so that they behave as desired.

1. Elements and Gamification Classification 
Gamification has three basic concepts of the game: activity objectives, reward mechanisms, and tracking of developments (Glover, 2013). The following is a brief review of the three concepts.

\subsection{Purpose of Activity}

In order to know clearly the difference between games and learning, students as gamification objects are directed to perform existing tasks. In terms of the game, if they have done the assignments the student will move to the next level or mission, according to the desired results. Meanwhile, in terms of learning, students can gain a more complete understanding of the complexity of the topic or material being studied (Ames, 1992; Pintrich, 2003). The application of such a strategy aims to enable students to master topics and skills in learning.

\subsection{Reward Mechanism}

There are many reward mechanisms used in the game. It depends on the context to be carried. However, there are three commonly used reward categories. First, leaderboards or boards. As the name suggests, leaderboards are players' ranking boards according to their success in the game.

A Leaderboards is a very crude technique as it is suitable for repetitive actions, but it can be a strong achievement motivation (although it provides less achievement motivation on the leaderboard achieved). Leaderboard is usually used in competitive activities but can also be used to encourage teamwork.

Prizes Computer games often feature customization elements that allow players to adapt their characters to the style of play they like or to adjust their character's appearance. This helps to make players more involved with the characters and provide a more customized playing experience. In games that feature customization options, the opportunity to obtain special items is usually associated with completing certain tasks in the game, and the desire for items provides achievement motivation for students to perform these tasks. Prizes can also take the form of additional activities, which will be opened after meeting the conditions of the previous goal. Different players will be motivated by different prizes and will carry out activities accordingly, and students will also be different this way. Prizes should encourage further involvement, such as organizing research assignments for groups, and should not prevent them, such as being released from the test.

Medals are icons that are displayed openly in an online profile that highlight activities completed by someone, and allow an individual to track what they have done and to 'show' to third parties. They can be seen as a combination of two other mechanisms and have recently become popular in many domains because of their inclusion in the latest popular gaming consoles.

1.3. Tracking progress

Like the learning process, tracking progress towards learning objectives is important in the game, because it would otherwise be impossible to identify the remaining tasks needed to meet the conditions of victory. Some of this tracking can be deduced from the 
reward mechanism, but this is a very simple measure and many games have a way to quickly identify tasks that are owned and have not been completed, and statistics on play in general. The method of tracking progression is somewhat analogous to providing feedback in education. Good feedback should outline what students have done and provide guidance on how to improve or progress in the future, and tracking progress in the game displays the same task by identifying steps taken to make it to the next milestone.

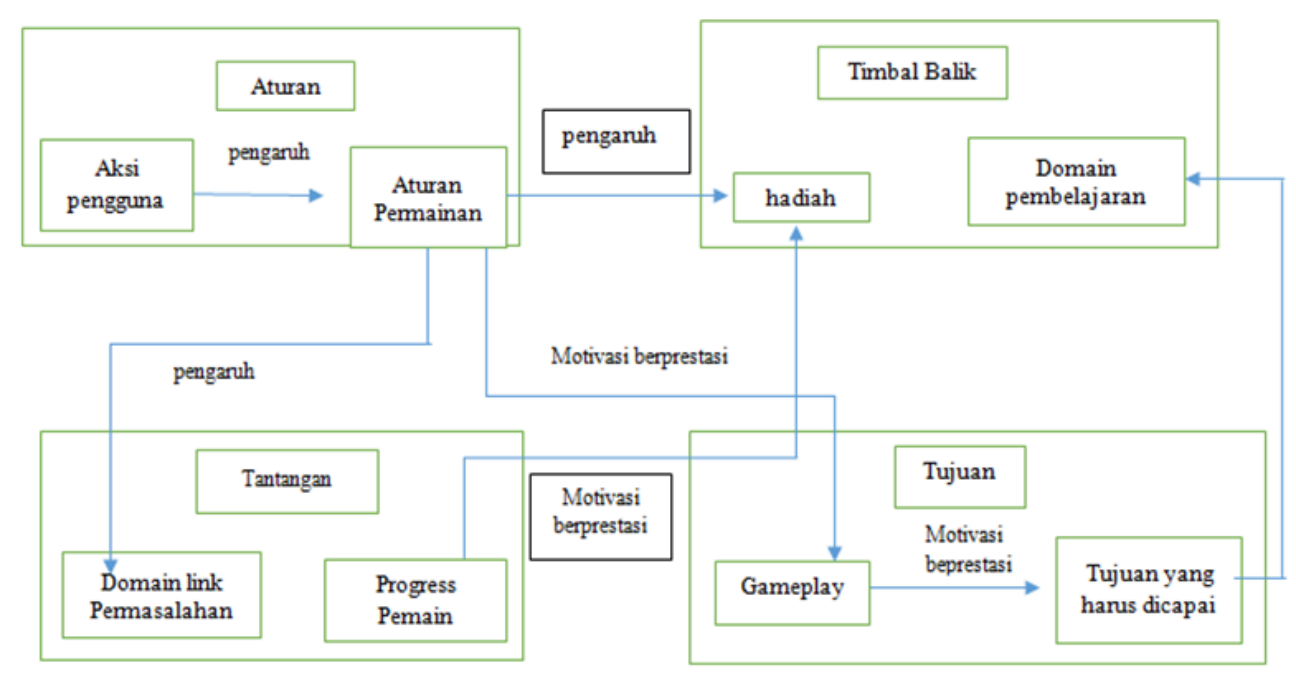

Figure 1. The basic components of the strategic design concept workflow

In the workflow of this gamification design concept the steps of the work procedure will be explained to its users (students), especially giving an overview of the learning outcomes. For this reason, gamification is no longer a packaging, but rather stimulates students to be able to increase achievement motivation in learning. Starting from there the design of this gamification workflow concept was made.

Table 1: Gamification Strategy Design for entrepreneurship courses

\begin{tabular}{|l|l|l|}
\hline \multicolumn{1}{|c|}{ Component } & \multicolumn{1}{|c|}{ Domain } & \multicolumn{1}{c|}{ Representation } \\
\hline The rules & Game theme & $\begin{array}{l}\text { The theme of the game for } \\
\text { entrepreneurship courses is business } \\
\text { creation }\end{array}$ \\
\cline { 2 - 3 } & Action game & $\begin{array}{l}\text { Presence, task management, and } \\
\text { curriculum management }\end{array}$ \\
\cline { 2 - 3 } & Rule of the game & $\begin{array}{l}\text { a) } \text { Tiered point system } \\
\text { b) single identity } \\
\text { c) each player can judge the results of } \\
\text { tasks performed by colleagues } \\
\text { associated with it }\end{array}$ \\
& $\begin{array}{l}\text { d) level of play is determined by the } \\
\text { success of the previous level } \\
\text { each reward in the form of gold can } \\
\text { be exchanged for additional value }\end{array}$ \\
\hline
\end{tabular}




\begin{tabular}{|l|l|l|}
\hline \multicolumn{1}{|c|}{ Component } & \multicolumn{1}{|c|}{ Domain } & \multicolumn{1}{c|}{ Representation } \\
\hline Purpose & Mechanical & $\begin{array}{l}\text { If the user gets more points, the greater } \\
\text { the chance to get rewards and level up }\end{array}$ \\
\cline { 2 - 3 } & Objectives & $\begin{array}{l}\text { students must be actively involved in the } \\
\text { completion of learning to get points and } \\
\text { feel enjoy in the game }\end{array}$ \\
\hline Challenge & Problem domain link & $\begin{array}{l}\text { Submit knowledge, complete schedules, } \\
\text { finishing tasks, conferences in the game. }\end{array}$ \\
\cline { 2 - 3 } & Progression & $\begin{array}{l}\text { Become the top user of the month, give an } \\
\text { assessment of the results of the } \\
\text { assignments of other friends. }\end{array}$ \\
\hline Feedback & Rewards & $\begin{array}{l}\text { Each level of student gets a different } \\
\text { assignment load and multi-level points }\end{array}$ \\
\hline & $\begin{array}{l}\text { Register 100 points } \\
\text { Attendance 1 point } \\
\text { Submit 10-point assignments } \\
\text { Top user of the month 100 points }\end{array}$ \\
\hline
\end{tabular}

\section{Entrepreneurship Course}

Entrepreneurship courses are subjects included in the general basic courses at the Faculty of Teacher Training and Education, Darul Ulum Lamongan Islamic University. This course is usually programmed in semester 5 with the weight of the semester credit unit (SKS) and semester hours is 2. This course is a compulsory course for students of the Teaching and Education Faculty (Guidelines for the Study of Islamic University Darul Ulum Lamongan, 2005).

Based on the explanation above, this course provides students with an understanding and appreciation of entrepreneurship which is increasingly felt important to face the era of globalization. The impact of the globalization era is competition which is getting tougher and resulting in some being able to survive (even survive) and even successful and some are less successful and then knocked out. To face the challenge, there is no other choice but to improve the quality of the available resources, especially human resources. Understanding and appreciation of entrepreneurship includes the role of the entrepreneur's mental attitude for self-improvement and institutions that have an entrepreneurial spirit and entrepreneurial mentality through the introduction of entrepreneurial characteristics, fostering business interest and tips for successful entrepreneurs. Making a business plan will provide provisions for students to be able to make business planning.

\section{Lee and Own Development Models}

In this development the development model with multimedia design was developed by Lee and Owens (2004). This development model consists of five stages, namely: (1) analysis (analysis); (2) design; (3) development (development); (4) implementation (implementation); and (5) evaluation. The development steps according to the Lee and Owen model can be seen in the following chart: 


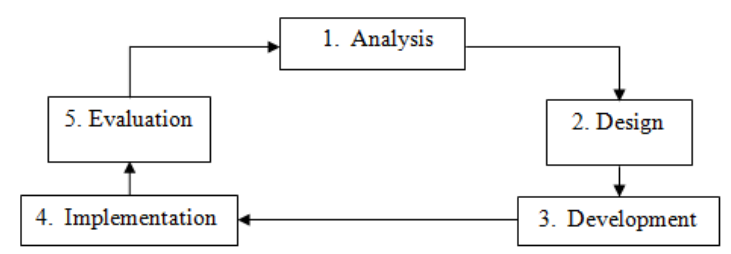

Figure 2. Lee and Owens Development Process (Lee \& Owens, 2004)

\section{Analysis Phase (analisys)}

1. Need assessment

Analyzing needs by finding information about student characteristics, learning objectives, and characteristics of teaching materials. The learning problems faced by students are different characteristics, where there are students who are quick to understand the material and there are also students who are slow to understand the material. In addition, another problem encountered in entrepreneurship courses is the lack of use of instructional media by lecturers.

2. Beginning to End Analysis (Front End Analyst)

After the needs analysis has been found, the next step is to collect detailed information about what needs to be improved by:

a. Analyzing students, that is identifying student backgrounds, learning characteristics, and prerequisite skills.

b. Analyzing the technological requirements needed.

c. Analyzing targets

d. Analyzing media

\section{Design Phase}

The initial stage and most important is to make a plan. As for what needs to be done in this planning are:

a. Determine the manufacturing schedule

b. Determine project team members

c. Determine media specifications

d. Create a content/material structure

e. Planning control configuration and review

\section{Development Phase (development)}

The development phase is the specification stage that has been designed and realized in the form of a program. The activities carried out in this development stage are making concept maps as outlined in the form of lesson plans, choosing background colors and feedback, compiling material styles and changes formatted in Microsoft Word, making layouts, storyboards, and other elements that can be used in perfecting product.

\section{Implementation Phase (implementation)}


The implementation phase is a follow-up to the development stage, meaning that products that have been developed can be used for learning because they have been tested both in terms of material and media. The purpose of this trial is to collect data about the quality of the products produced and the role of learning products in an effort to improve the quality of student learning outcomes. The trial was carried out through three stages, namely individual trials, small group trials, and field trials. The entire trial activities were carried out at FKIP Unisda Lamongan.

\section{Evaluation Phase}

The evaluation phase is carried out by considering several things including how to implement the evaluation strategy, the use of measuring tools and how to measure it, analyze and determine the system that will be used in analyzing data.

\section{CONCLUSION}

This development research seeks to design a gamification strategy in entrepreneurship courses in the Indonesian Language and Literature Study Program, FKIP UNISDA Lamongan. The Gamification Strategy developed has four basic game components, namely the rules of gamification, feedback (leaderboards, prizes, and medals), goals, and challenges. This research includes the type of development research that uses the Lee and Owl model with the following stages, (1) analyzing needs, (2) pre-test and posttest analysis, (3) design, (4) development, (5) implementation, (6) evaluation. Results of developing a gamification strategy package (1) gamification strategy (2) Lecturer guidance (3) student guide (4) Entrepreneurship book.

\section{REFERENCES}

Ames, C. (1992). Classrooms: Goals, structures, and student motivation. Journal of Educational Psychology, 84(3), 261.

Bransford, J., Sherwood, R., Vye, N., \& Rieser, J. (1986). Teaching thinking and problem solving: Research foundations. American Psychologist, 41(10), 1078.

Deterding, S., Dixon, D., Khaled, R., \& Nacke, L. (2011). From game design elements to gamefulness: defining gamification. Proceedings of the 15th International Academic MindTrek Conference: Envisioning Future Media Environments, 9-15. ACM.

Gagne, R. M. (1985). The conditions oflearning and theory ofinstruction. Hoit, Rinehart and Winston.

Gagné, R. M., Briggs, L., \& Wager, W. (1992). The events of instruction. Principles of Instructional Design, 177-197.

Glover, I. (2013). Play as you learn: gamification as a technique for motivating learners. EdMedia: World Conference on Educational Media and Technology, 1999-2008. Association for the Advancement of Computing in Education (AACE).

Kapp, K. (2014). Gamification of learning. Lynda. com.

Lee, W. W., \& Owens, D. L. (2004). Multimedia-based instructional design: computer- 
based training, web-based training, distance broadcast training, performance-based solutions. John Wiley \& Sons.

Pintrich, P. R. (2003). A motivational science perspective on the role of student motivation in learning and teaching contexts. Journal of Educational Psychology, 95(4), 667. 